Check for updates

1 London, UK

2 University of Edinburgh, Edinburgh, Scotland

3 The BMJ

Corresponding author: $\mathrm{M}$ Gill mgilm1@gmail.com

Cite this as: BMJ 2020;370:m2690 http://dx.doi.org/10.1136/bmi.m2690

Published: 07 July 2020

\section{Lessons from Leicester: a covid-19 testing system that's not fit for purpose}

\author{
England's chaotic system cost lives in Leicester and must be reformed \\ Mike Gill, ${ }^{1}$ Devi Sridhar, ${ }^{2}$ Fiona Godlee ${ }^{3}$
}

With the flare-up of covid-19 and re-imposition of lockdown, the population of Leicester is suffering the fallout of a chaotic testing system that seems to have forgotten its prime purpose, namely to trigger prompt, targeted measures, informed by local knowledge and up-to-date surveillance. Without swift and decisive action by those at local and national levels who understand communicable disease control, England will see further lockdowns and more avoidable deaths.

Leicester was a city at risk, with high levels of social deprivation and ethnic diversity. We now know that cases spiked in late May and that new cases were being detected throughout June at rates of over 100 per 100 ooo population per week. But these data were made available to the local authority only days before lockdown was re-imposed on $30 \mathrm{June}^{1}$ and were not made public for several days after that. In Germany the rates required to trigger local lockdown are 35-50 cases per 100 ooo per week, ${ }^{2}$ supported by a well functioning, locally based track and trace system.

\section{Delays and diversions}

Why did the local authority teams not have the data they needed to detect the outbreak and take swift action? In May, England's chief medical officer apologised to directors of public health for the lack of data from the so called pillar 2 system, which relies on private laboratories for testing in the community. General practitioners had been promised these data weeks before. ${ }^{3}$ It now seems clear that Public Health England (PHE) was itself receiving delayed, poor quality, and incomplete data from the private laboratories. Test results have been reaching PHE via a tortuous route encompassing the National Pathology Exchange and NHS Digital and often lack basic essential details such as NHS number and postcode. 4

Poor contracting seems partly to blame. Covid-19 was classed as a notifiable disease on 6 March, placing clear legal obligations on medical practitioners and laboratories for prompt reporting of all cases to PHE, 5 whether diagnosed or suspected. But this reporting obligation was not included in the contract with at least one of the private companies. ${ }^{6}$ These contracts seem to have focused on doing as many tests as possible, rather than establishing testing as a key component of a system designed to contain the virus and save lives.

Central government may also have caused delays. Up-to-date local data were available to PHE's rapid investigation team ${ }^{7}$ but were not shared with local authority teams, apparently on the orders of a government minister. ${ }^{8}$ It is hard to see what could justify such a prohibition. Local authorities have statutory public health duties and crucial local knowledge. ${ }^{9}$ Data sharing agreements have now been signed, but if a ministerial directive blocked timely data sharing, the minister should be held accountable for avoidable deaths and the consequences of reinforced lockdown. There could be a substantive legal case to answer.

PHE seems paralysed and divorced from the field of action. Its main response to data showing increasing incidence in Leicester was to increase test numbers rather than to initiate effective control measures-inaction that is all the more culpable given the city's population make up.

\section{Getting it right}

PHE is now, since 1 July, publishing data at local authority level, but only after mounting pressure and the prime minister's claim in parliament that data from both the NHS (PHE) and private testing systems "are shared with all authorities across the country." Wales has been doing this all along. Detailed data at postcode level are now being shared with local teams in England, but there are continuing concerns about quality and completeness (J DeGruchy, personal communication, 2020).

Many questions demand answers. How can new cases of a notifiable disease not be reported promptly to all those responsible for communicable disease control at a local level? In what way is England sufficiently different to Wales to justify such a crucial difference in reporting? Who decided, and on what basis, not to make disaggregated testing data available to local teams? Why should test results from a privately contracted laboratory be treated differently from those from NHS and PHE laboratories? And what is the plan for how to control spread in the other hotspots?

England's testing system stands in stark contrast to Scotland, which decided early on to build on existing capacity in local public health boards and ensure that tracing was locally led. Scotland has pursued a "zero covid" policy to drive down the number of cases through a test, trace, and isolate strategy, with daily reports on the Scottish government website of how many people were tested, how many tested positive, and other key indicators such as deaths and hospital admissions. This transparent approach is based on a clear strategy, underpinned by clear lines of accountability. Confirmed daily new cases are in the single digits and have consistently declined over the past few months. 
In the early days of the HIV epidemic understandable constraints were placed on how much detail about infections could be put into the public domain, on grounds of stigma, confidentiality, and very small numbers. With covid-19, precisely the opposite applies. Knowing how many covid-19 cases have been found in a locality will allow people to calibrate their response. As in the BSE crisis, the government's paternalistic, centralising tendency has meant that efforts to control the spread of the virus have been overwhelmed by a lack of trust not just in individuals to make their own decisions, but in local professionals and teams. ${ }^{10}$ This chaotic system has been established by a government with little understanding of communicable disease control. The announcement of a further $€ 5 \mathrm{bn}$

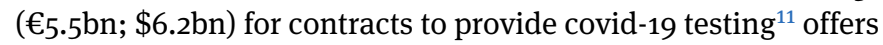
little hope for a change in direction.

Independent SAGE has called for an enhanced local response in Leicester, rooted in additional support for the affected population. ${ }^{12}$ Nationally, action is needed now if we are to avoid further damaging lockdowns. We need transparent and timely sharing of data, proper investment in local public health infrastructure, no more standalone testing systems, ${ }^{13}$ a fully functioning "find, test, trace, isolate, and support" system as set out by Independent SAGE, ${ }^{14}$ and a new determination to reduce levels of circulating virus, if we are to avoid the 30000 additional deaths by next April implied by England's chief medical officer. ${ }^{15}$

Provenance and peer review: Commissioned, not peer reviewed

Competing interests: We have read and understood BMJ policy on declaration of interests and declare the following interests: DS is a member of the Scottish covid-19 advisory group. FG and MG have no conflicts to declare.

1 Nazareth J, Minhas JS, Jenkins DR, etal. Early lessons from a second COVID-19 lockdown in Leicester, UK. Lancet 2020:. doi: 10.1016/S0140-6736(20)31490-2. pmid: 32622374

2 Reintjes R. Lessons in contact tracing from Germany. BMJ 2020;369:m2522. doi: 10.1136/bmj.m2522 pmid: 32586833

3 Pidd H, Garside J. "We have had zero information": GPs in the dark over Covid-19 tests. Guardian 2020 May 6. https://www.theguardian.com/world/2020/may/06/we-have-had-zero-informationgps-in-the-dark-over-covid-19-tests

4 Lintern S. Failing the test: slow start and flawed decisions in Britain's coronavirus testing have cost lives. Independent 2020 Jul. www.independent.co.uk/news/health/coronavirus-testinglighthouse-labs-nhs-deaths-delay-a9589381.html

5 Public Health England. Laboratories: report notifiable organisms (causative agents). https://www.gov.uk/guidance/notifiable-diseases-and-causative-organisms-how-to-report\#laboratories-report-notifiable-organisms-causative-agents

6 Written answer from Ms Nadine Dorries to WPQ 48980 on 11 June. https://twitter.com/justinmadders/status/1278257062561153024/photo/1

7 Public Health England. Rapid Investigation Team. Preliminary investigation into covid-19 exdeedances in Leicester (June 2020). https://assets.publishing.service.gov.uk/government/uploads/system/uploads/attachment_data/file/897128/COVID-19_activity_Leicester_Final-report_010720_V3.pdf

8 Burn-Murdoch J, Neville S, Hughes L, Bounds A. Lack of local covid-19 testing data hinders UK's outbreak response. Financial Times 2020 Jun 30. https://www.ft.com/content/301c847c-a3174950-a75b-8e66933d423a

9 Regulation 8. The Local Authorities (Public Health Functions and Entry to Premises by Local Healthwatch Representatives) Regulations. 2013 http://www.legislation.gov.uk/uksi/2013/351/made

10 Klein R. The politics of risk: the case of BSE. If we want less paternalism we must first educate ourselves. BMJ2000;321:1091-2. doi: 10.1136/bmj.321.7269.1091 pmid: 11061716

11 Garside J. UK set to award covid-19 testing contracts worth $£ 5$ bn to private bidders. Guardian 2020 Jul 2. https://www.theguardian.com/world/2020/jul/02/uk-set-to-award-covid-19-testingcontracts-worth-5bn-to-private-bidders

12 Independent SAGE. Statement on Leicester and local lockdowns. https://www.independentsage.org/independent-sage-statement-on-leicester-and-local-lockdowns/

13 Roderick P, Macfarlane A, Pollock AM. Getting back on track: control of covid-19 outbreaks in the community. BMJ2020;369:m2484. doi: 10.1136/bmj.m2484 pmid: 32586845

14 Independent SAGE. The Independent SAGE report 4. https://www.independentsage.org/wpcontent/uploads/2020/06/IndependentSAGE-report-4.pdf

15 Prime Minister's Office. Coronavirus press conference: 23 June 2020.
This article is made freely available for use in accordance with BMJ's website terms and conditions for the duration of the covid-19 pandemic or until otherwise determined by BMJ. You may use, download and print the article for any lawful, non-commercial purpose (including text and data mining) provided that all copyright notices and trade marks are retained. 